Bangladesh J. Bot. 41(2): 159-162, 2012 (December)

\title{
PREVALENCE OF PATHOGENIC BACTERIA IN COMMON SALAD VEGETABLES OF DHAKA METROPOLIS
}

\author{
FARJANA RAHMAN AND RASHED NOOR* \\ Department of Microbiology, Stamford University Bangladesh, \\ 51 Siddeswari Road, Dhaka-1217, Bangladesh
}

Key words: Raw vegetables, Pathogens, Fecal coliforms, Health risks

\begin{abstract}
Microbial quality of common salad vegetables (viz. carrot, cucumber, tomato and lettuce) collected from Dhaka metropolis was analysed to detect the presence of bacterial pathogens. The occurrence of huge numbers of fecal coliforms $\left(1.0 \times 10^{4}-4.09 \times 10^{6} \mathrm{cfu} / \mathrm{g}\right)$, Escherichia coli $\left(1.0 \times 10^{4}-5.0 \times 10^{8} \mathrm{cfu} / \mathrm{g}\right)$, Staphylococcus aureus $\left(2.0 \times 10^{5}-5.95 \times 10^{7} \mathrm{cfu} / \mathrm{g}\right)$, and Listeria spp. $\left(1.5 \times 10^{6}-6.5 \times 10^{7} \mathrm{cfu} / \mathrm{g}\right)$ were detected in all the tested samples. Interestingly, occurrence of viable but non-culturable (VBNC) bacteria was also noticed.
\end{abstract}

\section{Introduction}

Vegetables serve a major part of our food supply. Raw vegetables harbor a number of pathogenic microorganisms, which may be dispersed over the plants or appear as microcolonies embedded in the plant tissues (Beuchat 2002). During harvesting and transportation, raw vegetables may be bruised resulting in the release of plant nutrients, and thereby, providing substrates for microorganisms present on the surface of the vegetables to grow. In addition, the processing of fresh salad vegetables may alter or increase the number and type of pathogens present on the surface of the product. With a view of such exposure to pathogens, vegetables have been associated with the outbreaks of food borne disease in many countries (Alice 1997). Food borne illnesses can be caused mainly by microorganisms and/or their toxins. Cultivation of vegetables may largely account for such pathogenic contamination. Manures used to promote the growth of crops and vegetables contain a large number of pathogenic microorganisms including Salmonella, Escherichia coli O157:H7, Bacillus anthracis, Mycobacterium spp., Brucella spp., Listeria monocytogenes, Yersinia enterolytica, Clostridium perfringens, Klebsiella spp. and $M$. paratuberculosis (Alice 1997). Therefore, a great risk towards public health is posed by the organic fertilizers applied in the fields. The major bacterial diseases shaded are the various enteric diseases, diarrhoea, anthrax, salmonellosis, listeriosis, Crohn's disease, thrombocytopenic purpura, neurological disorders, arthritis, etc. (Cray and Moon 1995, Snowdon et al. 1989, Starutch 1991). Pathogens associated with untreated manure are assumed to enter into the food chain through crop. Thus, vegetables grown in such assistance of untreated fertilizers may play a significant role in showering pathogens to the consumers.

Therefore, an attempt was taken to assess the bacteriological quality, particularly pathogenic bacteria of fresh salad vegetables collected from several retail shops in Dhaka city.

\section{Materials and Methods}

A total of four different samples of common salad vegetables collected from different local markets and super shops of Dhaka City were used for microbiological analysis (Table 1). All the samples were collected according to the method suggested by American Public Health Association

*Author for correspondence: <noor.rashed@yahoo.com> 
(APHA 1998). A portion of $25 \mathrm{~g}$ of each vegetable sample was aseptically weighed and buffer peptone water was added to make the final volume $100 \mathrm{ml}$. Serial dilutions were made up to $10^{-5}$ for plating (Cappuccino and Sherman 1996).

For isolation of fecal coliforms such as Escherichia coli, Klebsiella spp., Staphylococcus aureus, and Listeria spp., MFC agar, MacConkey agar, Manitol Salt Agar (MSA) and Listeria isolation media were used. After incubation at $37^{\circ} \mathrm{C}$ except for fecal coliforms $\left(44.5^{\circ} \mathrm{C}\right)$ for $24 \mathrm{~h}$, observations were made for the characteristic colonies (Cappuccino and Sherman 1996). The presence of E. coli was further confirmed by the appearance of bluish-black colonies with the production of green metallic sheen on Eosin-Methylene Blue (EMB) agar medium. During isolation, enrichment was performed for Salmonella, Shigella (in selenite cystine broth) and for Vibrio spp. (in alkaline peptone water) in order to avoid the false negative results due to the possibility of these bacteria to be in stressed condition or in the viable but non-culturable (VBNC) state in the samples, thereby decreasing the chance of their cultivability in the isolation media (Oliver 2005, Colwell 2000). For Salmonella and Shigella spp., Xylose Lysine Deoxycholate (XLD) plates were used while for Vibrio spp., Thiosulfate Citrate Bile Salt Sucrose (TCBS) agar plates were used. After incubation at $37^{\circ} \mathrm{C}$ for $24 \mathrm{~h}$, characteristic colonies were detected and enumerated. Attempt was also taken to isolate Clostridium spp. from the vegetable samples (Francis et al. 1999).

Major biochemical tests such as Triple Sugar Iron (TSI), Motility Indole Urease (MIU), Methyl-Red (MR), Voges-Proskauer (VP), Citrate Utilization, Catalase test and Oxidase tests were carried out following the standard methods (Alfrad 2007, Cappuccino and Sherman 1996). All the experiments were performed in triplicate and the results were reproducible.

\section{Results and Discussion}

Fecal coliforms, E. coli, Staphyllococcus aureus and Listeria spp. were found to be the most frequently proliferating pathogens in the vegetable samples (Table 1). Klebsiella spp. were found only in tomato $\left(3.0 \times 10^{5}\right)$. The load of Vibrio spp., Salmonella spp. and Shigella spp. were found to be nil; however, upon enrichment, the number of these pathogenic bacteria was found significantly higher. Vibrio spp. was estimated upon enrichment within a range of $2.0 \times 10^{4}$ $8.3 \times 10^{7} \mathrm{cfu} / \mathrm{g}$ in carrot, lettuce and tomato samples, while Salmonella and Shigella spp. were found within a range of $1.0 \times 10^{3}-3.1 \times 10^{7} \mathrm{cfu} / \mathrm{g}$ and $3.0 \times 10^{4}-4.8 \times 10^{8} \mathrm{cfu} / \mathrm{g}$ respectively, in all samples. It is assumed that these pathogens were viable but non-culturable (VBNC) in the samples. A number of previous reports showed that Vibrio cholerae, V. parahaemolyticus, V. vulnificus, Salmonella and Shigella spp. may enter the VBNC state from which they are able to regain virulent properties after passaging in animal host (Colwell 2000, Huq et al. 2000, Olivier 2000, 2005). Thus, the assumed proliferance of the VBNC cells of Vibrio, Salmonella and Shigella spp. in fresh salad vegetables, as stated earlier, might be of significant interest in perspective of public health measure. All the isolates except Listeria spp. were confirmed through the biochemical tests (Table 2). It appears from the Table 1 that the samples from Shantinagar Bazar, Malibagh Bazar and Street site contained higher levels of microbial load than that of super shops. This might be due to the maintenance of hygienic condition with a relatively low storage temperature of the super shops. Prevalence of Staphylococci $\left(2 \times 10^{5}\right.$ to $\left.5.95 \times 10^{7} \mathrm{cfu} / \mathrm{g}\right)$ in all the salad samples is indicative of health risk upon consumption of these raw vegetables. Presence of indicator organisms, E. coli, Salmonella spp., Vibrio spp., Listeria spp. and Shigella spp. revealed the possibility of spreading enteric diseases to the consumers. Similar results were also reported by Khan et al. (2008) and Nipa et al. (2011) from the similar vegetables. 
Table 1. Bacterial load (cfu/g) of fresh vegetables.

\begin{tabular}{llllll}
\hline $\begin{array}{l}\text { Types of } \\
\text { vegetables }\end{array}$ & Source & $\begin{array}{l}\text { Fecal } \\
\text { coliform }\end{array}$ & $\begin{array}{l}\text { Escherichia } \\
\text { coli }\end{array}$ & $\begin{array}{l}\text { Staphylococcus } \\
\text { aureus }\end{array}$ & $\begin{array}{l}\text { Listeria } \\
\text { spp. }\end{array}$ \\
\hline Cucumber & Agora Super Shop & $2.00 \times 10^{4}$ & $5.00 \times 10^{4}$ & $2.00 \times 10^{5}$ & $2.13 \times 10^{6}$ \\
& Swapno Super Shop & $1.00 \times 10^{4}$ & $5.65 \times 10^{5}$ & $3.42 \times 10^{6}$ & $1.57 \times 10^{6}$ \\
& Malibag Bazar & $6.90 \times 10^{5}$ & $3.32 \times 10^{7}$ & $6.55 \times 10^{6}$ & $2.55 \times 10^{6}$ \\
& Shantinagar Bazar & $5.42 \times 10^{5}$ & $4.42 \times 10^{7}$ & $8.42 \times 10^{6}$ & $5.43 \times 10^{6}$ \\
& Street (Van) Sample & $7.20 \times 10^{5}$ & $5.02 \times 10^{6}$ & $4.34 \times 10^{6}$ & $1.54 \times 10^{7}$ \\
Carrot & Agora Super Shop & 0 & $1.00 \times 10^{4}$ & $1.57 \times 10^{6}$ & $2.06 \times 10^{6}$ \\
& Swapno Super Shop & 0 & $1.40 \times 10^{5}$ & $3.11 \times 10^{6}$ & $3.48 \times 10^{6}$ \\
& Malibag Bazar & $4.60 \times 10^{5}$ & $1.23 \times 10^{7}$ & $6.84 \times 10^{6}$ & $6.72 \times 10^{6}$ \\
& Shantinagar Bazar & $8.33 \times 10^{5}$ & $2.72 \times 10^{7}$ & $9.53 \times 10^{6}$ & $8.42 \times 10^{6}$ \\
& Street (Van) Sample & $3.73 \times 10^{6}$ & $3.48 \times 10^{7}$ & $1.32 \times 10^{7}$ & $5.42 \times 10^{7}$ \\
& Agora Super Shop & $3.00 \times 10^{4}$ & $6.50 \times 10^{5}$ & $4.31 \times 10^{7}$ & $1.50 \times 10^{6}$ \\
& Swapno Super Shop & $1.50 \times 10^{5}$ & $1.90 \times 10^{6}$ & $4.59 \times 10^{7}$ & $2.02 \times 10^{6}$ \\
& Malibag Bazar & $1.51 \times 10^{5}$ & $5.00 \times 10^{7}$ & $4.80 \times 10^{6}$ & $3.75 \times 10^{6}$ \\
& Shantinagar Bazar & $1.00 \times 10^{5}$ & $3.08 \times 10^{6}$ & $9.18 \times 10^{6}$ & $4.51 \times 10^{7}$ \\
& Street (Van) Sample & $3.00 \times 10^{6}$ & $5.00 \times 10^{8}$ & $5.95 \times 10^{7}$ & $5.00 \times 10^{7}$ \\
& Agora Super Shop & 0 & $2.20 \times 10^{5}$ & $5.00 \times 10^{4}$ & - \\
& Swapno Super Shop & $2.00 \times 10^{4}$ & $1.75 \times 10^{6}$ & $5.50 \times 10^{6}$ & - \\
& Malibag Bazar & $7.09 \times 10^{5}$ & $2.40 \times 10^{7}$ & $5.00 \times 10^{5}$ & $2.00 \times 10^{5}$ \\
& Shantinagar Bazar & $1.32 \times 10^{6}$ & $5.03 \times 10^{7}$ & $3.00 \times 10^{4}$ & $5.50 \times 10^{6}$ \\
& Street (Van) Sample & $4.09 \times 10^{6}$ & $1.23 \times 10^{8}$ & $5.02 \times 10^{6}$ & $6.50 \times 10^{7}$ \\
\hline
\end{tabular}

Table 2. Results of biochemical tests of the pathogenic isolates.

\begin{tabular}{|c|c|c|c|c|c|c|c|c|c|c|c|c|}
\hline \multicolumn{4}{|c|}{ TSI } & \multirow[t]{2}{*}{ Motility } & \multirow{2}{*}{$\begin{array}{c}\text { Indole } \\
\text { produc- } \\
\text { tion }\end{array}$} & \multirow{2}{*}{$\begin{array}{l}\text { Urease } \\
\text { activity }\end{array}$} & \multirow[t]{2}{*}{ MR } & \multirow[t]{2}{*}{$\mathrm{VP}$} & \multirow{2}{*}{$\begin{array}{c}\text { Citrate } \\
\text { utiliza- } \\
\text { tion }\end{array}$} & \multirow{2}{*}{$\begin{array}{c}\text { Catalase } \\
\text { test }\end{array}$} & \multirow{2}{*}{$\begin{array}{l}\text { Oxidase } \\
\text { test }\end{array}$} & \multirow{2}{*}{$\begin{array}{c}\text { Identified } \\
\text { organism }\end{array}$} \\
\hline Slant & Butt & Gas & $\mathrm{H}_{2} \mathrm{~S}$ & & & & & & & & & \\
\hline A & A & + & - & + & + & - & + & - & + & - & - & Escherichia coli \\
\hline A & A & - & - & - & - & + & - & - & - & + & - & Klebsiella spp. \\
\hline A & K & + & + & + & - & ND & + & - & + & ND & ND & Salmonella spp. \\
\hline A & A & + & - & + & + & ND & + & - & - & ND & ND & Shigella spp. \\
\hline+ & + & - & - & - & - & - & + & - & - & + & - & $\begin{array}{l}\text { Staphylococcus } \\
\text { aureus }\end{array}$ \\
\hline A & A & - & - & + & + & ND & + & - & + & ND & + & Vibrio spp. \\
\hline
\end{tabular}

$\mathrm{A}=$ Acidic reaction, $\mathrm{K}=$ Alkaline reaction, $\mathrm{MR}=$ Methyl red, $\mathrm{VP}=$ Voges-Proskauer, $\mathrm{ND}=$ Not done, $+=$ Positive, - = Negative.

An important aspect of this study was the isolation of Listeria spp. from the salad vegetables which has been reported to represent an imperative risk to public health globally (Liu 2006, Little et al. 2007, Jeyaletchumi et al. 2010). Thus, the present study adds new insight to the existing knowledge on the microbiology of the commonly consumed fresh salads in Bangladesh. Another interesting facet from this study lies on the existence of VBNC state of the pathogens in the salad vegetables. Extensive identification of such cells would further unveil the factual implications of such bacteria on food borne epidemic outbreaks. 


\section{Acknowledgements}

The authors are thankful to Kazi Kaniz Fatema and Kamal Kanta Das, Department of Microbiology, Stamford University Bangladesh, for their technical assistance.

\section{References}

APHA 1998. (American Public Health Association). Standard Methods for the Examination of Water and Wastewater. 20th Ed., American Public Health Association, Washington, D.C.

Alice NP 1997. Manure and Microbes: Public and Animal Health Problem? J. Dairy Sci. 80(10): 2673-2681.

Alfrad EB 2007. Bensons Microbiological Applications. Mcgraw-Hill Book Company, New York. pp. 263280.

Beuchat LR 2002. Ecological factors influencing survival and growth of human pathogens on raw fruits and vegetables. Microb. Infect. 4(4): 413-423.

Cappuccino JG and Sherman N 1996. Microbiology - A Laboratory Manual, 4th ed. The Benjamin/ Cummings Publishing Co., Inc., Menlo Park, California. pp. 13-182.

Cray WCJ and Moon WH 1995. Experimental infection of calves and adult cattle with Escherichia coli O157:H7. Appl. Environ. Microbiol. 61(4):1586-1590.

Colwell RR 2000. Bacterial death revisited. In: Non-culturable microorganisms in the environment, Colwell RR and Grimes DJ (Eds), pp. 325-342. American Soc. Microbiol., Washington DC, USA.

Francis GA, Thomas C and O’beirne D 1999. Microbiological safety of minimally processed vegetables. Int. J. Food Sci Tech. 34(1): 1-22.

Huq A, Rivera ING and Colwell RR 2000. Epidemiological significance of viable but nonculturable microorganisms. In: Non-culturable microorganisms in the environment, Colwell RR and Grimes DJ (Eds), pp. 301-324. American Soc. Microbiol., Washington DC, USA.

Jeyaletchumi P, Tunung R, Margaret SP, Son R, Ghazali FM, Cheah YK, Nishibuchi M, Nakaguchi Y and Malakar PK 2010. Quantification of Listeria monocytogenes in salad vegetables by MPN-PCR. Int. Food Res. J. 17(2): 281-286.

Khan MR, Saha ML and Kibria AHMG 2008. A bacteriological profile of salad vegetables in Bangladesh with special reference to coliforms. Letter Appl. Microbiol. 14(3): 88-90.

Little CL, Taylor FC, Sagoo SK, Gillespie IA and McLuachin GK 2007. Prevalence and level of Listeria monocytogenes and other Listeria species in retail pre-packaged mixed vegetable salads in the UK. Food Microbiol. 24(7-8): 711-717.

Liu D 2006. Identification, subtyping and virulence determination of Listeria monocytogenes, an important foodborne pathogen. J. Med. Microbiol. 55(6): 645-659.

Nipa MN, Mazumdar RM, Hasan MM, Fakruddin M, Islam S, Bhuiyan HR and Iqbal A 2011. Prevalence of multi-drug resistant bacteria on raw salad vegetables sold in major market of Chittagong City, Bangladesh. Middle-East J. Sci. Res. 10(1): 70-77.

Oliver JD 2005. The viable but nonculturable state in bacteria. J. Microbiol. 43: 93-100.

Oliver JD 2000. The public health significance of viable but non-culturable bacteria. In: Non-culturable microorganisms in the environment, Colwell RR and Grimes DJ (Eds), pp. 277-300. American Soc. Microbiol., Washington DC, USA.

Snowdon JA, Cliver DO and Converse JC 1989. Land disposal of mixed human and animal wastes: A review. Waste Manag. Res. 7:121-134.

Starutch D 1991. Survival of pathogenic microorganisms and parasites in excreta, manure sand sewage sludge. Rev. Sci. Tech. Off. Int. Epiz. 10(3):813-846. 